\title{
ZAKRES I SKUTKI DEPENALIZACJI WYWOLANEJ NOWELIZACJĄ PRZEPISU OKREŚLAJĄCEGO ZNAMIONA PRZESTĘPSTWA NIEALIMENTACJI
}

Ustawą z 23 marca 2017 r. o zmianie ustawy - Kodeks karny oraz usta-

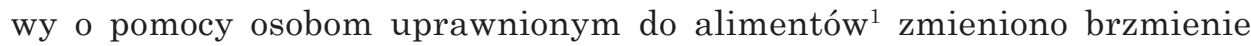
art. 209 k.k. W wyniku tej nowelizacji wskazany artykuł otrzymał nowa strukturę składającą się z sześciu przepisów o następującej treści:

§ 1. Kto uchyla się od wykonania obowiązku alimentacyjnego określonego co do wysokości orzeczeniem sądowym, ugodą zawartą przed sądem albo innym organem albo inną umowa, jeżeli łączna wysokość powstałych wskutek tego zaległości stanowi równowartość co najmniej 3 świadczeń okresowych albo jeżeli opóźnienie zaległego świadczenia innego niż okresowe wynosi co najmniej 3 miesiące, podlega grzywnie, karze ograniczenia wolności albo pozbawienia wolności do roku.

$\S 1$ a. Jeżeli sprawca czynu określonego w $§ 1$ naraża osobę uprawnioną na niemożność zaspokojenia podstawowych potrzeb życiowych, podlega grzywnie, karze ograniczenia wolności albo pozbawienia wolności do lat 2.

$\S 2$. Ściganie przestępstwa określonego w § 1 lub 1a następuje na wniosek pokrzywdzonego, organu pomocy społecznej lub organu podejmującego działania wobec dłużnika alimentacyjnego.

$\S 3$. Jeżeli pokrzywdzonemu przyznano odpowiednie świadczenia rodzinne albo świadczenia pieniężne wypłacane w przypadku bezskuteczności egzekucji alimentów, ściganie przestępstwa określonego w $§ 1$ lub 1a odbywa się z urzędu.

$\S 4$. Nie podlega karze sprawca przestępstwa określonego w $§ 1$, który nie później niż przed upływem 30 dni od dnia pierwszego przesłuchania w charakterze podejrzanego uiścił w całości zaległe alimenty.

§ 5. Sąd odstępuje od wymierzenia kary, jeżeli nie później niż przed upływem 30 dni od dnia pierwszego przesłuchania $\mathrm{w}$ charakterze podejrzanego sprawca przestępstwa określonego w $§ 1$ a uiścił w całości zaległe alimenty, chyba że wina i społeczna szkodliwość czynu przemawiaja przeciwko odstapieniu od wymierzenia kary.

Tym samym odstapiono od poprzednio obowiązującej wersji art. 209 k.k., która - przypomnijmy - była następująca:

$\S 1$. Kto uporczywie uchyla się od wykonania ciążącego na nim z mocy ustawy lub orzeczenia sądowego obowiązku opieki przez niełożenie na utrzymanie osoby najbliższej lub innej osoby i przez to naraża ją na niemożność zaspokojenia podstawowych potrzeb życiowych, podlega grzywnie, karze ograniczenia wolności albo pozbawienia wolności do lat 2.

${ }^{1}$ Zob. Dz. U. 2017, poz. 952. 
$\S 2$. Ściganie następuje na wniosek pokrzywdzonego, organu pomocy społecznej lub organu podejmującego działania wobec dłużnika alimentacyjnego.

$\S$ 3. Jeżeli pokrzywdzonemu przyznano odpowiednie świadczenia rodzinne albo świadczenia pieniężne wypłacane w przypadku bezskuteczności egzekucji alimentów, ściganie odbywa się $\mathrm{z}$ urzędu.

Wskazana zmiana rodzi zatem pytanie o jej zakres i skutki w sferze materialnego prawa karnego. To, iż w jej wyniku doszło w pewnym fragmencie do istotnego zaostrzenia stosunku prawa karnego wobec osób uchylających się od obowiązków alimentacyjnych, nie budzi wątpliwości². Gołym okiem jest bowiem widoczna nowość w postaci wyodrębnienia na gruncie przestępstwa niealimentacji rygorystyczniej ujętych podstawowych i kwalifikowanych jego postaci, które określono w art. 209 k.k., odpowiednio w $§ 1 \mathrm{i}$ w $\S 1 \mathrm{a}$. Wskazany kierunek zmian polega - krótko mówiąc - na tym, że w przypadku obu tych postaci zrezygnowano z warunku uporczywości ${ }^{3}$, a w przypadku postaci podstawowych nadto odstapiono od wymogu narażenia osoby, względem której obowiąek alimentacyjny powinien być wykonywany, na niemożność zaspokojenia jej podstawowych potrzeb życiowych ${ }^{4}$. W niniejszym opracowaniu nie będę jednak analizował powyższych zmian. Skupię się na kwestii zakresu ewentualnej depenalizacji wywołanej nowelizacją art. 209 k.k. Kwestia ta nie była bowiem do tej pory dyskutowana.

Z uwagi na cel rozważań analizą objęte zostaną tylko te paragrafy art. 209 k.k., które w poprzednim oraz obecnym stanie prawnym wyznaczały oraz wyznaczaja zakres kryminalizacji. Przypomnijmy zatem, że w poprzednim stanie prawnym przepisem tego rodzaju był art. $209 \S 1$ k.k., natomiast w obecnym stanie prawnym przepisami pełniącymi funkcję kryminalizującą są dwa przepisy znajdujące się w art. 209 k.k., mianowicie $\S 1$ i $§ 1$ a tego artykułu.

Aby odpowiedzieć na pytanie o zakres ewentualnej depenalizacji, musimy - co zrozumiałe - przeprowadzić wykładnię tych przepisów ${ }^{5}$. Bez jej zrealizowania, zwieńczonego odtworzeniem zawartych w nich norm sankcjonowanych $^{6}$, nie jest bowiem możliwa stosowna analiza porównawcza.

Zatem wykładnia poprzednio obowiązującego art. $209 \S 1 \mathrm{k} . \mathrm{k}$. skutkuje odtworzeniem zeń następujących norm sankcjonowanych zaadresowanych do osoby zobowiązanej do alimentacji:

${ }^{2}$ Zob. M. Małecki, Przestepstwo niealimentacji w perspektywie zmian (uwagi do rzqdowego projektu nowelizacji art. 209 k.k. z 28 października 2016 r.), „Czasopismo Prawa Karnego i Nauk Penalnych" 20, 2016, z. 4, s. 37 i n.

${ }^{3}$ Por. M. Małecki, op. cit., s. 42.

${ }^{4}$ Okoliczność ta sprawia, że podstawowe typy przestępstwa niealimentacji są zatem przestępstwami bezskutkowymi (formalnymi).

${ }^{5}$ Przyjmujemy bowiem założenie o normatywności tekstu prawnego. Szerzej nt. tego założenia zob. M. Zieliński, Wyktadnia prawa. Zasady, reguty, wskazówki, Warszawa 2010, s. 11 i n.

${ }^{6}$ A więc norm, których treściowa charakterystyka dostarcza nam informacji o klasie zachowań zakazanych przez owe normy i tym samym zabronionych przez nie pod groźbą kary. Przyjmujemy bowiem założenie, że z odtwarzalnych z przepisu prawa karnego norm prawnych to właśnie norma sankcjonowana jest tą norma, której treść decyduje o tym, jakiego rodzaju zachowania sa zabronione pod groźbą kary. Szerzej na temat tego założenia zob. Ł. Pohl, Struktura normy sankcjonowanej w prawie karnym. Zagadnienia ogólne, Poznań 2007, s. 55 i n., a także idem, Prawo karne. Wyktad części ogólnej, Warszawa 2015, s. 55 i n. 
1) zakazującej jej uporczywego uchylania się od wykonania ciążącego na niej z mocy ustawy obowiązku opieki przez niełożenie na utrzymanie osoby najbliższej, narażające tę osobę na niemożność zaspokojenia podstawowych potrzeb życiowych;

2) zakazujacej jej uporczywego uchylania się od wykonania ciążącego na niej z mocy ustawy obowiązku opieki przez niełożenie na utrzymanie osoby nie najbliższej, narażające tę osobę na niemożność zaspokojenia podstawowych potrzeb życiowych;

3) zakazującej jej uporczywego uchylania się od wykonania ciążącego na niej z mocy orzeczenia sądowego obowiązku opieki przez niełożenie na utrzymanie osoby najbliższej, narażające tę osobę na niemożność zaspokojenia podstawowych potrzeb życiowych;

4) zakazujaccej jej uporczywego uchylania się od wykonania ciążącego na niej z mocy orzeczenia sądowego obowiązku opieki przez niełożenie na utrzymanie osoby nie najbliższej, narażające tę osobę na niemożność zaspokojenia podstawowych potrzeb życiowych ${ }^{7}$.

Z kolei z obecnie obowiązujaccego art. $209 \S 1$ k.k. odtwarzalne są następujące, również zaadresowane do osoby zobowiązanej do alimentacji, normy sankcjonowane:

1) zakazująca jej uchylania się od wykonania obowiązku alimentacyjnego określonego co do wysokości orzeczeniem sądowym - w sytuacji gdy łączna wysokość powstałych wskutek tego zaległości stanowi równowartość co najmniej 3 świadczeń okresowych;

2) zakazujacca jej uchylania się od wykonania obowiązku alimentacyjnego określonego co do wysokości orzeczeniem sądowym - w sytuacji gdy opóźnienie zaległego świadczenia innego niż okresowe wynosi co najmniej 3 miesiące;

3) zakazujacca jej uchylania się od wykonania obowiązku alimentacyjnego określonego co do wysokości ugodą zawartą przed sądem - w sytuacji gdy łączna wysokość powstałych wskutek tego zaległości stanowi równowartość co najmniej 3 świadczeń okresowych;

4) zakazująca jej uchylania się od wykonania obowiązku alimentacyjnego określonego co do wysokości ugodą zawartą przed sądem - w sytuacji gdy opóźnienie zaległego świadczenia innego niż okresowe wynosi co najmniej 3 miesiace;

5) zakazujacca jej uchylania się od wykonania obowiązku alimentacyjnego określonego co do wysokości ugodą zawartą przed innym organem - w sytuacji gdy łączna wysokość powstałych wskutek tego zaległości stanowi równowartość co najmniej 3 świadczeń okresowych;

${ }^{7}$ Mnoga liczba norm sankcjonowanych zawartych w poprzednio obowiązującym art. $209 \S 1$ k.k. zaświadcza o tym, że przepis ten był przepisem pluralnym, ustawodawca bowiem posłużył się w nim techniką kondensacji wielu norm w jednym przepisie. Na temat tej techniki zob. M. Zieliński, op. cit., s. 134 i n. Przy sposobności podkreślmy, że w karnistyce technikę tę omawia się pod hasłem „przestępstwo wieloodmianowe” - zob. Ł. Pohl, Struktura normatywna przepisu o tzw. przestęstwie wieloodmianowym, „Państwo i Prawo” 61, 2006, z. 10, s. 74 i n., w którym to artykule w szczególności zwrócono uwagę na to, że spotykana w karnistyce konwencja mówienia o jednym przestępstwie w przypadku przestępstwa wieloodmianowego jest $\mathrm{z}$ teoretycznoprawnego punktu widzenia nieuzasadniona. 
6) zakazująca jej uchylania się od wykonania obowiązku alimentacyjnego określonego co do wysokości ugodą zawartą przed innym organem - w sytuacji gdy opóźnienie zaległego świadczenia innego niż okresowe wynosi co najmniej 3 miesiace;

7) zakazująca jej uchylania się od wykonania obowiązku alimentacyjnego określonego co do wysokości inną umową - w sytuacji gdy łączna wysokość powstałych wskutek tego zaległości stanowi równowartość co najmniej 3 świadczeń okresowych;

8) zakazująca jej uchylania się od wykonania obowiązu alimentacyjnego określonego co do wysokości inną umowa - w sytuacji gdy opóźnienie zaległego świadczenia innego niż okresowe wynosi co najmniej 3 miesiące ${ }^{8}$.

Nadto w obecnym stanie prawnym - za sprawa art. 209 § 1a k.k. - obowiazuja jeszcze kwalifikowane typy wszystkich wyliczonych wyżej ośmiu norm. Ich kwalifikujacym elementem treściowym jest wywołane przez zobowiązanego do alimentacji zachowaniami opisanymi w art. $209 \S 1 \mathrm{k} . \mathrm{k}$. narażenie uprawnionego do alimentów na niemożność zaspokojenia jego podstawowych potrzeb życiowych ${ }^{9}$.

Przystępując do wykazania różnic o ewentualnym skutku depenalizacyjnym pomiędzy treścią wskazanych wyżej norm sankcjonowanych zakodowanych w nieobowiązującej już wersji art. $209 \S 1$ k.k. i norm sankcjonowanych zakodowanych w obecnie obowiązującej wersji art. 209 § 1 i 1a k.k., wskażmy, że w warstwie deskryptywnej poprzednio obowiązującego art. $209 \S 1$ k.k. w odróżnieniu od obecnie obowiązującego art. 209 § 1 i 1a k.k. - nie nawiązywano do kwestii wysokości obowiązku alimentacyjnego. W zakresie charakterystyki tego obowiązku wskazywano w niej bowiem wyłącznie na źródło tego obowiązku. Oznaczało to w konsekwencji, że w poprzednio obowiązującym stanie prawnym jednym z możliwych wariantów wypełnienia znamion przestępstwa niealimentacji było ich wypełnienie w sytuacji braku uprzedniego określenia wysokości obowiązku alimentacyjnego. Tymczasem w obecnym stanie prawnym wypełnienie znamion przestępstwa niealimentacji w sytuacji wskazanego braku wydaje się niemożliwe, gdyż - jak powiedziano - przekroczenie każdej z obowiązujących norm sankcjonowanych odtwarzalnych z art. $209 \S 1$ i 1a k.k. uwarunkowane jest, przynajmniej na etapie językowej wykładni wskazanych przepisów, uprzednim określeniem wysokości obowiązku alimentacyjnego. Można by oczywiście podejmować jeszcze próbę przełamania tego rezultatu na etapie wykładni pozajęzykowej, polegającej na uruchomieniu stosownych dyrektyw funkcjonalnych ${ }^{10}$, ale wydaje się - koniec końców że brakuje tu wystarczających podstaw do takiego przełamania i tym samym uznania, że uprzednie określenie wysokości obowiązku alimentacyjnego nie jest warunkiem koniecznym wypełnienia znamion przestępstwa niealimentacji w obecnym stanie prawnym. Nie sposób bowiem dowieść, że otrzymany $\mathrm{w}$ wyniku zastosowania językowych dyrektyw intepretacyjnych rezultat w po-

\footnotetext{
${ }^{8}$ I w tym przepisie zastosowano zatem technikę kondensacji wielu norm.

${ }^{9}$ Zatem także art. 209 § 1a k.k. jest przepisem pluralnym, zawierającym wiele norm sankcjonowanych.

${ }^{10}$ Szerzej nt. tego rodzaju dyrektyw zob. M. Zieliński, op. cit., s. 342.
} 
staci wymogu uprzedniego określenia wysokości obowiązku alimentacyjnego jest rezultatem, który burzy podstawowe założenia o racjonalności prawodawcy $^{11}$, tym bardziej że w pełni konweniuje on ze słuszną i znajdująca umocowanie w konstytucyjnej zasadzie proporocjonalności ideą postrzegania prawa karnego jako instrumentu uruchamianego po wyczerpaniu innych i zarazem mniej dolegliwych środków prawnego oddziaływania (prawo karne jako ultima ratio). Słowem, wedle tej zasady represja karna powinna się w rozważanych przypadkach uaktywniać w szczególności po nieskutecznym oddziaływaniu środków cywilnoprawnych ${ }^{12}$. Zresztą o niemożliwości odstapienia od wyinterpretowanego na etapie wykładni językowej wymogu uprzedniego określenia wysokości obowiązku alimentacyjnego przesądza niejako z góry dyrektywa absolutnego zakazu wykładni rozszerzającej jednoznacznego językowo przepisu przyznającego określonemu podmiotowi kompetencję do dokonania doniosłej prawnie czynności konwencjonalnej. Jak wskazuje bowiem Maciej Zieliński, nigdy - a więc także wtedy, gdy dochodzimy do wniosku, że językowe znaczenie burzy podstawowe założenia o racjonalności prawodawcy - nie wolno rozszerzająco zinterpretować takiego przepisu ${ }^{13}$. Co do tego natomiast, że przepisy art. $209 \S 1$ i 1 a k.k. sa przepisami przyznającymi wskazaną kompetencję, nie można mieć żadnych wątpliwości. Zawierają one bowiem zaadresowane do sądu normy sankcjonujące, w których zakresie zastosowania centralne miejsce zajmuje właśnie ustalenie, że doszło do przekroczenia którejśs z zawartych $\mathrm{w}$ omawianym artykule norm sankcjonowanych. Innymi słowy, odstapienie od wymogu uprzedniego określenia wysokości obowiązku alimentacyjnego byłoby rozszerzająca wykładnią centralnego elementu hipotezy (zakresu zastosowania) tych norm. Wobec powyższego uznać należy, że we wskazanym wyżej zakresie nowelizacja art. 209 k.k. - pomimo odmiennego punktu widzenia zaprezentowanego przez projektodawcę w jej uzasadnieniu ${ }^{14}$ - jest zmiana normatywną o depenalizacyjnym charakterze.

11 Przypomnijmy bowiem - w ślad za M. Zielińskim - że: „Znaczenie językowe burzy system wartości, jeśli przy przyjęciu tego znaczenia należałoby odrzucić którąś z wartości zasadniczych przypisywanych prawodawcy lub którąś z wartości instrumentalnych stanowiących warunek konieczny dla zasadniczej" - idem, op. cit., s. 342-343.

12 Z tego też względu analizowaną nowelizację art. 209 k.k. należy ocenić w pełni pozytywnie. $\mathrm{W}$ miejscu tym podnieśmy także, że takie postrzeganie prawa karnego nie oznacza, że z tego powodu jest ono prawem spełniajacym jedynie funkcję zabezpieczającą. Za bezzasadny uznać bowiem należy pogląd (głoszony przede wszystkim przez karnistów wywodzących się z tzw. krakowskiej szkoły prawa karnego), że prawo karne nie pełni funkcji regulującej, oddziałującej na organizację prywatnego i społecznego życia człowieka.

${ }^{13}$ Zob. M. Zieliński, op. cit., s. 343.

${ }^{14} \mathrm{~W}$ uzasadnieniu tym wskazano bowiem, że: „Nowelizacja obejmuje przy tym świadomą rezygnację z przywołania w art. 209 § 1 k.k. ustawy jako samoistnego źródła obowiązu alimentacyjnego. Argumentem przemawiającym za takim rozwiązaniem był fakt, że zdaniem projektodawcy w tym zakresie jest to norma pusta i w rzeczywistości nie zdarzają się przypadki, w których jedyną i wyłączną podstawą ustaleń organów w toku postępowania karnego w zakresie istnienia obowiązku alimentacyjnego, jego formy oraz wysokości byłaby ustawa" - zob. Projekt zmiany ustawy - Kodeks karny wraz z uzasadnieniem, s. 3-4 (druk nr 1193 z 3 stycznia 2017 r.). Otóż raz jeszcze podkreślmy, że z racji braku wyartykułowania w poprzednio obowiązującej wersji art. 209 $\S 1$ k.k. wymogu uprzedniego określenia wysokości obowiązku alimentacyjnego normy sankcjonowane odtwarzalne z tego przepisu można było przekroczyć także w sytuacji braku sądownego czy umownego określenia wysokości tego obowiązku. Podnoszona przez projektodawcę okoliczność, 
Sformułowanie w obowiązującym art. 209 § 1 i 1a k.k. wymogu uprzedniego określenia wysokości obowiązku alimentacyjnego spowodowało też depenalizację zachowań polegających na uchylaniu się od niepieniężnych świadczeń alimentacyjnych. Wskazany skutek zmiany prawa był zakładany przez projektodawcę. W uzasadnieniu nowelizacji art. $209 \mathrm{k} . \mathrm{k}$. podniesiono bowiem, że rezygnacja $\mathrm{z}$ penalizacji uchylania się od wszelkiego rodzaju świadczeń alimentacyjnych jedynie na rzecz świadczeń określonych co do wysokości (tj. świadczeń pieniężnych) jest celowa, gdyż: „[...] w istocie tylko z taka forma niewykonywanych świadczeń alimentacyjnych mają do czynienia organy ścigania i sądy w postępowaniu karnym"15.

Nadto nie można też wykluczyć depenalizacyjnego oddziaływania znajdującego się w art. $209 \S 1$ k.k. sformułowania:

jeżeli łączna wysokość powstałych wskutek tego zaległości stanowi równowartość co najmniej 3 świadczeń okresowych albo jeżeli opóźnienie zaległego świadczenia innego niż okresowe wynosi co najmniej 3 miesiące.

Nowelizacja art. 209 k.k. wywołała zatem depenalizację trzech typów zachowań. Pierwszy z nich obejmuje zachowania, którymi wypełniono znamiona przestępstwa niealimentacji w sytuacji braku uprzedniego - sądownego czy umownego - określenia wysokości obowiązku alimentacyjnego. Będą to więc zachowania, które sąd uznał za zabronione pod groźbą kary tylko na tej podstawie, że sprawca uporczywie uchylał się od wykonania ciążącego na nim z mocy ustawy obowiązku alimentacyjnego. Drugim są zachowania, które polegają na uporczywym uchylaniu się od wykonania obowiązku alimentacyjnego w postaci świadczenia niepieniężnego. Trzecim są natomiast niedające się z góry wykluczyć, a więc teoretycznie możliwe, przypadki, w których skazanie za przestępstwo niealimentacji nastapiło pomimo niespełnienia - nieobowiązującego wówczas - warunku wynikającego ze sformułowania:

iż - w jego ocenie - nie zdarzają się przypadki, w których jedyną i wyłączną podstawą ustaleń organów w toku postępowania karnego o czyn z art. $209 \S 1$ k.k. byłaby ustawa, nie może - co oczywiste - oddziaływać na wyznaczony tym przepisem zakres kryminalizacji. Ten bowiem jest absolutnie niezależny od rzeczywistości kryminalnej; brak przypadków naruszenia normy nie przesądza bowiem o jej nieobowiązywaniu. Zresztą uważam, że należałoby dokładnie sprawdzić, czy przekonanie projektodawcy o braku wskazanych przypadków - przekonanie, jak się wydaje, $\mathrm{w}$ dużej mierze intuicyjnie uzasadnione - znajduje potwierdzenie w praktyce postępowania organów ścigania i wymiaru sprawiedliwości. Nadmieńmy, że w uzasadnieniu omawianej nowelizacji wskazano jeszcze nadto, że: „[...] w znowelizowanym przepisie projektodawca poszerzył źródła obowiązku alimentacyjnego o ugodę zawartą przed sądem albo innym organem albo inną umowę. W świetle obowiązujących przepisów również bowiem wymienione tytuły stanowią podstawę ustalenia świadczeń alimentacyjnych” - zob. op. cit., s. 4. Otóż pogląd o poszerzeniu źródeł obowiązku alimentacyjnego nie jest w pełni trafny, gdyż - jak trafnie ujął to T. Smyczyński - „Bezwzględny charakter norm regulujących powstanie, wykonanie i wygaśnięcie obowiązku alimentacyjnego sprawia, że wola stron tego stosunku prawnego ma znikomy wpływ na jego istnienie i realizację" idem, Prawo rodzinne i opiekuńcze, Warszawa 1997, s. 207. Słowem, wymienione w art. $209 \S 1$ k.k. źródła - w postaci: orzeczenia sądowego, ugody zawartej przed sądem, ugody zawartej przed innym organem oraz umowy między stronami stosunku alimentacyjnego - nie są źródłami obowiązku alimentacyjnego, a jedynie - w kontekście art. 209 § 1 i 1a k.k. - źródłami informującymi o wysokości obowiązku alimentacyjnego.

${ }^{15}$ Zob. Projekt..., s. 4. Jedynie na marginesie pozwolę sobie na uwagę, że w mojej ocenie depenalizacja w tym zakresie nie jest uzasadniona. 
jeżeli łączna wysokość powstałych wskutek tego zaległości stanowi równowartość co najmniej 3 świadczeń okresowych albo jeżeli opóźnienie zaległego świadczenia innego niż okresowe wynosi co najmniej 3 miesiące.

W przypadku wskazanych zachowań powinien zatem - i to obligatoryjnie znaleźć zatosowanie art. $4 \S 4$ k.k., przewidujacy zatarcie skazania z mocy prawa w przypadku, gdy czyn objęty wyrokiem nie jest już zabroniony pod groźba kary ${ }^{16}$. Sąd, który wydał wyrok skazujący za popełnienie przestępstwa niealimentacji, powinien zatem, procedując wówczas według stosownych przepisów k.k.w., możliwie dokładnie sprawdzić, czy zachowanie, za które sprawca został skazany na podstawie poprzednio obowiązującej wersji art. $209 \S 1$ k.k., byłoby zachowaniem zabronionym pod groźbą kary, gdyby popełniono je pod rządami obecnie obowiązujacej ustawy karnej. Obliguje go do tego - jak powiedziano norma wyrażona w art. $4 \S 4$ k.k. Jest przy tym rzeczą najzupełniej jasna, że rozstrzygnięcie tej kwestii nie może się ograniczać do analizy charakterystyki tego zachowania znajdującej się $\mathrm{w}$ treści wyroku ${ }^{17}$. Charakterystyka ta - z natury rzeczy - jest bowiem w dużym stopniu zdeterminowana językiem prawnym (słownictwem) przepisu będącego podstawą skazania. Tym samym nie jest ona miarodajna w sytuacji zmiany tego języka. $Z$ taka zaś zmianą mamy do czynienia w przypadku omawianej nowelizacji. Oznacza to - koniec końców - że warunkiem zastosowania art. $4 \S 4$ k.k. jest dokonanie przez sąd oceny całościowej rozważanego zachowania, a więc oceny bazującej m.in. na konieczności ponownego zbadania przezeń akt sprawy. Sąd nie może tu zatem poprzestać na analizie sentencji wyroku. Musi on - raz jeszcze to podkreślmy - możliwie wszechstronnie i dokładnie ustalić, czy zachowanie, za które pociagną on do odpowiedzialności karnej z tytułu wypełnienia nim w sposób przestępny znamion czynu zabronionego określonego w poprzednio obowiąującej wersji art. 209 § 1 k.k., byłoby zachowaniem zabronionym pod groźbą kary w sytuacji, gdyby popełniono je pod rządami obecnie obowiazującego k.k. W art. $4 \S 4$ k.k. mowa jest bowiem o statusie prawnym zachowania objętego wyrokiem skazującym, a nie o charakterystyce tego zachowania przedstawionej w tym wyroku, a w szczególności w jego sentencji. Słowem, skrajnie błędną praktyką interpretacyjna byłoby - niestety już spotykane ${ }^{18}$ - bazowanie przez sąd wyłącznie na rzeczonej charakterystyce. W znajdującym się w art. $4 \S 4$ k.k. wyrażeniu „czyn objęty wyrokiem” chodzi bowiem nie o ujęty w tym wyroku sądowy opis tego czynu, lecz o konkretny czyn będący w tym wyroku podstawą skazania.

prof. dr hab. Eukasz Pohl

Uniwersytet Szczecinski

lukasz.pohl@wpiaus.pl

${ }_{16}$ Przypomnijmy, że zgodnie z tym przepisem: „Jeżeli według nowej ustawy czyn objęty wyrokiem nie jest już zabroniony pod groźbą kary, skazanie ulega zatarciu z mocy prawa”.

17 Tymczasem z doniesień medialnych wynika, że sądy ograniczają się do tej charakterystyki - zob. P. Balinowski, Skazani za długi alimentacyjne moga wyjść na wolność. Może chodzić o tysiace osób, http://www.rmf24.pl/fakty/polska/news-skazani-za-dlugi-alimentacyjne-moga-wyjsc-na-wolnosc-moze-ch,nId,2404033 [dostęp: 7.12.2017].

18 Odnotował to bowiem w przywołanym wyżej artykule już T. Balinowski. 


\section{THE SCOPE AND CONSEQUENCES OF DE-PENALISATION ARISING FROM THE AMENDMENTS TO THE PROVISION DEFINING THE FAILURE TO PAY CHILD SUPPORT}

Sum mary

The article deals with the scope of de-penalisation resulting from the amendments to Article 209 of the Penal Code and subsequent proper interpretation of Article $4 \S 4$ of the same code. 